\title{
Efficiency of K-sulphate and K-feldspar Combined with Silicate Dissolving Bacteria on Yield and Nutrient Uptake by Maize Plants
}

\author{
Abdel-Rahaman M.A. Merwad \\ Soils Science Dept., Fac. Agric., Zagazig Univ., Egypt.
}

\begin{abstract}
FIELD experiment was carried out in 2014 growing season in Hehia, El-Sharkia Governorate, Egypt to asses application of 95 $\mathrm{kg} \mathrm{K} \mathrm{ha}^{-1}$ applied to maize (Zea mays) as potassium sulphate (KS) or potassium feldspar (KS) combined with potassium dissolving bacteria (i.e., silicate dissolving bacteria "SDB", Bacillus circullans) individually or in different combination ratios. 50\% KS + 50\% KF gave the highest values of height of maize plants, leaf area, ear length, ear diameter, ears yield, stover and grains dry weight, NPKuptake, protein content and biological yield. The treatments of $25 \%$ $\mathrm{KS}+75 \% \mathrm{KF}$ and control gave the lowest among the treatments receiving $\mathrm{K}$. The application of $50 \% \mathrm{KS}+50 \% \mathrm{KF}$ gave increases in stover and grains dry weight which ranged from $40-51 \%$ and $87-$ $118 \%$, respectively. The treatment of (K3) at 45, 90 and 180 days gave the highest value of soil available potassium $(295,375$ and 247 $\mathrm{mg} \mathrm{kg}^{-1}$, respectively), while the lowest ones $\left(63,58\right.$ and $51 \mathrm{mg} \mathrm{kg}^{-1}$, respectively) were found with untreated soil.
\end{abstract}

Keywords: Potassium sulphate, Potassium feldspar, Nutrient uptake, Maize, Bacillus circullans.

Maize (Zea mays L.) is a cereal of high economic relevance and a variety use (Fancelli and Dourado, 2003) ranging from food and feed to the high-technology industries (Paes, 2008). Potassium (K) is one of the macronutrient essential for maize growth and plays an important role in plant growth, metabolism and development. Without adequate potassium, the plants will have poorly developed roots, grow slowly, produce small seeds and have lower yields. Soluble potassium in soils is frequently not sufficient for high production of maize , although most soils have high contents of insoluble forms of potassium (Sheng and Huang, 2002). In Egypt, farmers apply high rates of chemical potassium fertilizers (such as potassium sulphate) to maize. The high price of chemical fertilizers contributes to increasing production cost of crops, which may be one of the reasons for us aiming at providing plants with $\mathrm{K}$ released from mineral non- soluble sources (Manning, 2010 and Labib et al., 2012). The use of rhizobacteria including potassium solubilizing bacteria as biofertilizers was suggested as a sustainable solution for crop fertilization (Vessey, 2003, Sheng, 2005, Setiawati \& Handayanto, 2010 and Ekin, 2010). Potassium solubilizing bacteria is a heterotrophic aerobic bacteria which obtain their energy and cellular carbon from organic material sources in soil (Zakaria, 2009) and play an important role in maintaining soil structure by their contribution in forming 
water-stable soil aggregates. These bacteria are able to solubilize rock $\mathrm{K}$, such as micas, illite and orthoclases (feldspar), also through production and excretion of organic acids ( Ullman et al., 1996) by chelating silicon ions releasing K into solution (Bennett et al., 1998). Potassium solubilizing bacteria Bacillus mucilaginosus were reported to have increased $\mathrm{K}$ availability in soils and increased mineral content in plant (Sheng et al., 2002 and Zakaria, 2009). Bakken et al. (2005) reported that fertilizers containing biotite as its main $\mathrm{K}$ bearing mineral and between 5 and $20 \%$ carbonate, released $\mathrm{K}$ at a slower rate than soluble K fertilizer. Girgis et al. (2008) showed that inoculation with potassium solubilizing bacteria caused partial degradation of minerals resulting in the release of soluble $\mathrm{K}$ and $\mathrm{P}$. Badr (2006) used potassium solubilizing bacteria to enhance available $\mathrm{K}$ in the matured compost. Response of potato plants to K-biofertilizer was enhanced in sandy soil of low K content (Sugiyama and Ae, 2006). Priyono and Gilkes (2008) evaluated the effectiveness of intensively milled gneiss and potassium feldspars as $\mathrm{K}$-fertilizers with ryegrass and concluded that such materials are most advantageous for amending $\mathrm{K}$ deficient soils. Abd El-Hakeem and Fekry (2014) reported that addition of 50\% potassium sulphate plus $50 \% \mathrm{~K}$ - feldspar + silicate dissolving bacteria (SDB) increased yield and NPK-uptake. Abdel-Salam \& Shams (2012) and Labib et al. (2012) applied $50 \%$ potassium sulphate $+50 \%$ K- feldspar combined with SDB gave the highest quality parameters of potato tubers, total yield and NPK uptake. The objective of the current study is to asses $\mathrm{K}$ fertilization $(\mathrm{K}$ - sulphate and $\mathrm{K}$ feldspar) of maize through the use silicate dissolving bacteria.

\section{Material and Methods}

A field experiment was carried out during 2014 growing season in Hehia , Egypt to study the asses of the efficiency of $\mathrm{K}$ fertilization (K- sulphate and $\mathrm{K}$ feldspar combined with silicate dissolving bacteria "SDB" of Bacillus circullans) to maize (Zea mays L.,cv. 2031 hybrid). The physical and chemical properties of the soil (Table 1) were determined according to Piper (1950); Black (1968) and Jackson (1958).

The experiment was done using the randomized complete block design in three replicates. It involved application of $\mathrm{K}$ at $95 \mathrm{~kg} \mathrm{ha}^{-1}$ to maize as $\mathrm{K}$-sulphate (KS) or K-feldspar (KF) or combination of both. Treatments were as follows:

- Non-fertilized (K0)

- $100 \% \mathrm{KS}(\mathrm{K} 1)$

- $75 \% \mathrm{KS}+25 \% \mathrm{KF}(\mathrm{K} 2)$

- $50 \% \mathrm{KS}+50 \% \mathrm{KF}(\mathrm{K} 3)$

- $25 \% \mathrm{KS}+75 \% \mathrm{KF}(\mathrm{K} 4)$

- $100 \% \mathrm{KF}(\mathrm{K} 5)$ 
TABLE 1. Some physical and chemical properties of the investigated soil.

\begin{tabular}{|c|c|}
\hline Soil characteristics & Values \\
\hline \multicolumn{2}{|c|}{ Soil particles distribution } \\
\hline Sand , \% & 47.92 \\
\hline Silt, \% & 18.25 \\
\hline Clay, $\%$ & 33.83 \\
\hline Textural class & Sandy Clay Loam \\
\hline Field capacity (FC), $\%$ & 27.95 \\
\hline $\mathrm{CaCO}_{3},\left(\mathrm{~g} \mathrm{~kg}^{-1}\right)$ & 18.5 \\
\hline Organic matter, $\left(\mathrm{g} \mathrm{kg}^{-1}\right)$ & 4.4 \\
\hline $\mathrm{pH}^{*}$ & 7.95 \\
\hline $\mathrm{EC},\left(\mathrm{dSm}^{-1}\right) * *$ & 1.12 \\
\hline \multicolumn{2}{|c|}{ Soluble cations and anions, $\left(\right.$ mmolc $\left.\mathrm{L}^{-1}\right) * *$} \\
\hline $\mathrm{Ca}^{++}$ & 4.54 \\
\hline $\mathrm{Mg}^{++}$ & 2.32 \\
\hline $\mathrm{Na}^{+}$ & 2.91 \\
\hline $\mathrm{K}^{+}$ & 1.24 \\
\hline $\mathrm{CO}_{3}=$ & - \\
\hline $\mathrm{HCO}_{3}^{-}$ & 1.56 \\
\hline $\mathrm{Cl}^{-}$ & 3.44 \\
\hline $\mathrm{SO}_{4}=$ & 6.01 \\
\hline \multicolumn{2}{|c|}{ Available nutrient,$\left(\mathrm{mg} \mathrm{kg}^{-1}\right.$ soil $)$} \\
\hline $\mathrm{N}$ & 109 \\
\hline $\mathrm{P}$ & 11.23 \\
\hline $\mathrm{K}$ & 182 \\
\hline
\end{tabular}

The KS contained $410 \mathrm{~g} \mathrm{~K} \mathrm{~kg}^{-1}$ whereas $\mathrm{KF}$ contained $95 \mathrm{~g} \mathrm{~K} \mathrm{~kg}^{-1}$. The plot area was $21 \mathrm{~m}^{2}(3 \times 7 \mathrm{~m})$, each plot had five rows $60 \mathrm{~cm}$ apart and $7 \mathrm{~m}$ long. All treatments received $240 \mathrm{~kg} \mathrm{~N}$ (as ammonium sulphate, $200 \mathrm{~g} \mathrm{~N} \mathrm{~kg}^{-1}$ ) $+30 \mathrm{~kg} \mathrm{P}$ (as ordinary super phosphate, $68 \mathrm{~g} \mathrm{P} \mathrm{kg}^{-1}$ ). N- fertilizer was applied in 3 equal splits 15, 40 and 60 days after seeding $\mathrm{P}$ and $\mathrm{K}$ fertilizers were applied during land preparation. The K- feldspar inoculated with silicate dissolving bacteria, "SDB", (Bacillus circullans) in a concentration of $\left(10^{10}\right.$ cells $\left.\mathrm{ml}^{-1}\right)$ at rate of 20 $\mathrm{ml} \mathrm{kg}^{-1} \mathrm{~K}$ - feldspar; and is produced commercially by Soil Microbiology Unit of National Research Centre, Cairo, Egypt.

At harvest, plant samples were separated into stover and grains, dried at $70^{\circ} \mathrm{C}$, ground and digested with concentrated mixture of $\mathrm{H}_{2} \mathrm{SO}_{4} / \mathrm{HCLO}_{4}$ for chemical analysis (Chapman and Pratt, 1961). Total N was determined using the microKjeldahl method according to Chapman and Pratt (1961). P was determined colourmetrically using ascorbic acid (Watanabe and Olsen, 1965), 
while $\mathrm{K}$ was measured by flame photometer. Soil samples were taken after tittering, booting and harvest stages (45, 90 and 180 days after seeding) and available potassium was determined according to Chapman and Pratt (1961).

\section{Results and Discussion}

Plant growth parameters, stover and grain yields

Data presented in Table 2 show that all treatments significantly increased the height of plants, leaf area, ear length, ear diameter, ear yield, stover and grain dry yield and biological yield.

TABLE 2. Effect of potassium sulphate (KS) and potassium feldspar (KF) treated with silicate dissolving bacteria on plant growth measurements, stover and grains dry weight of maize plants.

\begin{tabular}{|c|c|c|c|c|c|c|c|c|}
\hline Treatment & $\begin{array}{c}\text { Plant } \\
\text { height } \\
\text { (m) }\end{array}$ & $\begin{array}{l}\text { Leaf } \\
\text { area } \\
\left(\mathrm{cm}^{2}\right)\end{array}$ & $\begin{array}{c}\text { Ear } \\
\text { length } \\
(\mathrm{cm})\end{array}$ & $\begin{array}{c}\text { Ear } \\
\text { diameter } \\
(\mathbf{c m})\end{array}$ & $\begin{array}{l}\text { Ear yield } \\
(\mathrm{Mg} \mathrm{ha-1})\end{array}$ & $\begin{array}{l}\text { Grain } \\
\text { yield } \\
(\mathrm{Mg} \\
\left.\mathrm{ha}^{-1}\right)\end{array}$ & $\begin{array}{c}\text { stover } \\
\text { yield } \\
\left(\text { Mg ha }^{-1}\right)\end{array}$ & $\begin{array}{c}\text { Biological } \\
\text { yield } \\
\left(\mathrm{Mg} \mathrm{ha}^{-1}\right)\end{array}$ \\
\hline K0 & 2.68 & 453 & 14.33 & 4.43 & 5.46 & 3.44 & 9.79 & 15.44 \\
\hline K1 & 3.41 & 661 & 21.33 & 5.70 & 8.21 & 6.43 & 14.00 & 22.21 \\
\hline $\mathrm{K} 2$ & 3.15 & 559 & 17.67 & 5.03 & 7.01 & 4.97 & 12.28 & 19.33 \\
\hline K3 & 3.52 & 726 & 20.67 & 6.17 & 9.19 & 7.52 & 15.03 & 24.22 \\
\hline K4 & 3.0 & 491 & 16.00 & 4.73 & 6.15 & 4.29 & 11.33 & 17.48 \\
\hline K5 & 3.22 & 596 & 19.33 & 5.40 & 7.06 & 5.25 & 13.17 & 20.17 \\
\hline Means & 3.16 & 581 & 18.22 & 5.24 & 7.18 & 5.32 & 12.60 & 19.81 \\
\hline LSD $0.05 \%$ & 0.03 & 28.14 & 4.69 & 0.22 & 0.45 & 0.324 & 0.33 & 0.63 \\
\hline
\end{tabular}

Treatments are K0: no $-\mathrm{K}$; K1, K2, K3, K4 and $\mathrm{K} 5$ of $\mathrm{KS} 100 \%, 75 \% \mathrm{KS}+25 \% \mathrm{KF}, 50 \% \mathrm{KS}+$ $50 \% \mathrm{KF}, 25 \% \mathrm{KS}+75 \% \mathrm{KF}$ and $\mathrm{KF} 100 \%\left(100 \%\right.$ is $\left.95 \mathrm{~kg} \mathrm{~K} \mathrm{ha}^{-1}\right)$.

Application of $\mathrm{K} 3$ gave the highest positive response which followed the pattern $\mathrm{K} 3>\mathrm{K} 1>\mathrm{K} 5>\mathrm{K} 2>\mathrm{K} 4>\mathrm{K} 0$. The increases regarding grain yield were $119,87,53,44$ and $24 \%$ due $\mathrm{K} 3, \mathrm{~K} 1, \mathrm{~K} 5, \mathrm{~K} 2$ and $\mathrm{K} 4$, respectively; comparable increases regarding ear yield were 68, 50, 29, 28 and 13, respectively. These results are in agreement with those obtained by Abdel-Salam \& Shams (2012) and Abd El-Hakeem \& Fekry (2014).

The highest values of ears and stover yields given by fertilized treatments were obtained by the $50 \% \mathrm{~K}$-sulphate $+50 \% \mathrm{~K}$-feldspar (K3), while the lowest was obtained by the $25 \% \mathrm{~K}$-sulphate $+50 \% \mathrm{~K}$-feldspar (K4). Therefore with half of the $\mathrm{K}$ rate given as feldspar, the silicate dissolving bacteria (SDB) seemed of high activity. The use of SDB and the positive response obtained by such bacteria with feldspars was reported by Vessey (2003); Sheng (2005); Dawwam et al., (2013) and Priyanka \& Sindhu (2013). Potassium dissolving bacteria play an important role in formation of humus in soil and cycling of minerals tied up in organic matter (Zakaria, 2009). Solubilization of rock- K, through production and excretion of organic acids or through chelating silicate ions to bring $\mathrm{K}$ into solution (Ullman et al., 1996). Inoculation with potassium solbilizing bacteria either potassium or feldspar was applied slowly or integrated might provide

Egypt. J. Soil Sci. 56, No. 2 (2016) 
faster and continuous supply of $\mathrm{K}$ for improving plant growth, yield and its quality (Badr et al., 2006; Eweda et al., 2007; Abdel-Salam \& Shams, 2012 and Abou-El-Seousd \& Abdel-Megeed , 2012).

\section{Nutrient uptake}

Data in Table 3 indicate that all treatments increased stover and grains N, P and K-uptake by maize plants as compared to control (untreated). The K3 gave the highest $\mathrm{N}, \mathrm{P}$ and $\mathrm{K}$-uptake in stover and grains. The treatment of K4 showed the lowest one of the fertilized treatments. The pattern was $\mathrm{K} 3>\mathrm{K} 1>\mathrm{K} 5>\mathrm{K} 2>$ K4 > K0. The increases regarding N, P and K uptake in grain were 230,165,107, 78 and $39 \%$ for N-uptake due K3, K1, K5, K2 and K4, respectively; 487, 328 , 205, 149 and 59\% for P-uptake; comparable increases regarding K-uptake were $215,146,89,68$ and 35 , respectively. These results are in agreement with those obtained by Foth (1990) and Abd El-Hakeem \& Fekry (2014) who used applied $\mathrm{K}$ as $50 \%$ potassium sulphate plus $50 \% \mathrm{~K}$ - feldspar combined with SDB and increased yield of sweet potato as well as increased uptake of $\mathrm{N}$ and $\mathrm{K}$. The current results are similar to those reported by Abdel-Salam \& Shams (2012) and Labib et al. (2012) who applied $50 \%$ potassium sulphate $+50 \% \mathrm{~K}$ - feldspar + $\mathrm{SDB}$ ) and obtained high yield as well as N, P and K uptake in tubers and shoots of potato plants.

TABLE 3. Effect of potassium sulphate (KS) and potassium feldspar(KF) treated with silicate dissolving bacteria on stover and grains N,P and $K$ uptake $\left(\mathrm{kg} \mathrm{ha}^{-1}\right)$ by maize plants.

\begin{tabular}{|c|c|c|c|c|c|c|}
\hline \multirow{2}{*}{ Treatment } & \multicolumn{3}{|c|}{ Stover } & \multicolumn{3}{c|}{ Grains } \\
\cline { 2 - 7 } & $\begin{array}{c}\text { N- } \\
\text { uptake }\end{array}$ & $\begin{array}{c}\text { P- } \\
\text { uptake }\end{array}$ & $\begin{array}{c}\text { K- } \\
\text { uptake }\end{array}$ & $\begin{array}{c}\text { N- } \\
\text { uptake }\end{array}$ & $\begin{array}{c}\text { P- } \\
\text { uptake }\end{array}$ & $\begin{array}{c}\text { K- } \\
\text { uptake }\end{array}$ \\
\hline K0 & 101 & 11.98 & 18.46 & 46.96 & 5.85 & 76.06 \\
\hline K1 & 226 & 13.88 & 39.91 & 124.9 & 25.08 & 187.00 \\
\hline K2 & 170 & 28.64 & 30.62 & 83.86 & 14.59 & 128.00 \\
\hline K3 & 254 & 55.6 & 45.53 & 155.4 & 34.34 & 240.00 \\
\hline K4 & 136 & 21.55 & 26.46 & 65.30 & 9.31 & 103.00 \\
\hline K5 & 201 & 36.88 & 34.63 & 97.74 & 17.87 & 144.00 \\
\hline Means & 181.3 & 28.09 & 32.60 & 95.69 & 17.84 & 146.00 \\
\hline LSD 0.05\% & 11.82 & 3.44 & 1.85 & 8.93 & 2.26 & 10.55 \\
\hline
\end{tabular}

Treatments are K0: no -K; K1, K2, K3, K4 and K5 of KS 100\%, 75\% KS+25\% KF, 50\% KS + 50\% $\mathrm{KF}, 25 \% \mathrm{KS}+75 \% \mathrm{KF}$ and $\mathrm{KF} 100 \%\left(100 \%\right.$ is $\left.95 \mathrm{~kg} \mathrm{~K} \mathrm{ha}^{-1}\right)$.

\section{Quality yield of maize}

Data presented in Table 4 show that the application of treatment K3 gave the highest harvest index, shelling ratio, protein content and the 100 grain weight $(31.06,81.85,11.78 \%$ and $38.71 \mathrm{~g}$, respectively), while the lowest one was obtained with untreated soil (without application of K) , $(22.28,63,7.97 \%$ and $26 \mathrm{~g}$, respectively). Quality values followed the pattern of $\mathrm{K} 3>\mathrm{K} 1>\mathrm{K} 5>\mathrm{K} 2>$ 
K4 > K0. The increases regarding protein content were 47, 39, 33, 20 and 10\% due $\mathrm{K} 3, \mathrm{~K} 1, \mathrm{~K} 5, \mathrm{~K} 2$ and $\mathrm{K} 4$, respectively; comparable increases regarding the 100 grain weight were $48,36,29,20$ and 15 , respectively. These results are agreement with those obtained by Xiong et al. (2007) who found that $\mathrm{K}$ increased forage maize yield and quality yield. Abd El-Hakeem and Fekry (2014) reported that $50 \%$ potassium sulphate $+50 \% \mathrm{~K}$ - feldspar+ SDB improved the quality of tuber roots and total sugar in sweet potato and Abd El-Baky et al. (2010) reported positive effect on sweet potato and Sugiyama \& Ae (2006) and Labib et al. (2012) reported positive effect on potato.

TABLE 4. Effect of potassium sulphate(KS) and potassium feldspar (KF) treated with silicate dissolving bacteria on quality yield of maize plants.

\begin{tabular}{|l|c|c|c|c|}
\hline Treatment & $\begin{array}{c}\text { Protein content } \\
(\boldsymbol{\%})\end{array}$ & $\begin{array}{c}\text { Harvest index } \\
(\boldsymbol{\%})\end{array}$ & $\begin{array}{c}\text { Shelling ratio } \\
(\boldsymbol{\%})\end{array}$ & $\begin{array}{c}\text { 100 Grain weight } \\
(\mathbf{g})\end{array}$ \\
\hline K0 & 7.97 & 22.28 & 63.00 & 26.06 \\
\hline K1 & 11.08 & 28.95 & 78.33 & 35.41 \\
\hline K2 & 9.61 & 25.72 & 70.47 & 31.33 \\
\hline K3 & 11.78 & 31.06 & 81.85 & 38.71 \\
\hline K4 & 8.78 & 24.57 & 69.88 & 29.93 \\
\hline K5 & 10.60 & 26.04 & 75.00 & 33.58 \\
\hline Means & 9.97 & 26.44 & 73.09 & 32.50 \\
\hline LSD 0.05\% & 10.55 & 1.14 & 0.84 & 1.08 \\
\hline
\end{tabular}

Treatments are K0: no $-\mathrm{K}$; K1, K2, K3, K4 and $\mathrm{K} 5$ of $\mathrm{KS} 100 \%, 75 \% \mathrm{KS}+25 \% \mathrm{KF}, 50 \% \mathrm{KS}+50 \%$ $\mathrm{KF}, 25 \% \mathrm{KS}+75 \% \mathrm{KF}$ and $\mathrm{KF} 100 \%\left(100 \%\right.$ is $\left.95 \mathrm{~kg} \mathrm{~K} \mathrm{ha}^{-1}\right)$.

Available potassium in soil

Data illustrated in Fig. 1 represent the values of available potassium $\left(\mathrm{mg} \mathrm{kg}^{-1}\right)$ in the treated soil with $\mathrm{K}$-sulphate or $\mathrm{K}$-feldspar inoculated with SDB during different periods after seeding (45, 90 and 180 days). The treatment of 50\% KS + $50 \% \mathrm{KF}$ gave the highest values of available potassium $(295,375$ and $247 \mathrm{mg}$ $\mathrm{ka}^{-1}$, respectively), while the lowest ones $(62.9,58.4$ and50.8 mg kg-1 respectively,) were obtained with untreated soil during the indicated periods. These results are in agreement with those obtained by Blum and Stillings (1995). The pattern of comparison among treatments was rather similar to those regarding yields of grains and ears. These results are similar to those by Bader (2006) who found that the highest release of potassium was consistent up the end of composting process (feldspar +compost $+\mathrm{SDB}$ ) after 90 days of incubation.

As a general result, the available potassium showed remarkably increase after 90 days at all treatments. These increases may be due to the microbial activity which has the ability to affect soil reaction in the soil microenvironment leading to solubilizing mineral $\mathrm{K}$. This finding is in agreement with those obtained by Blum \& Stillings (1995), Bader et al. (2006) and Merwad et al. (2013). 


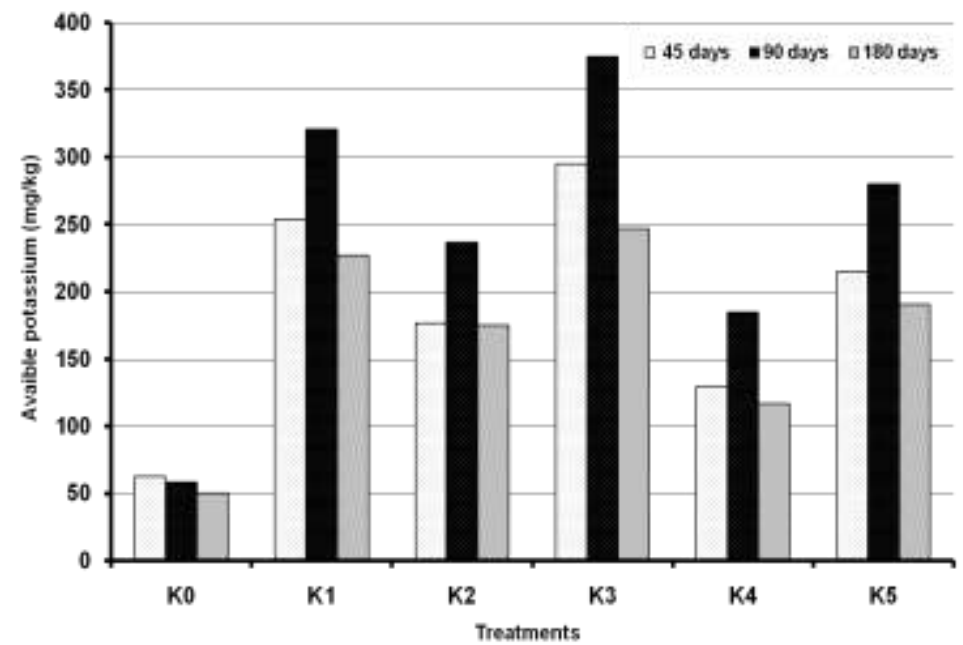

Treatments are K0: no $-\mathrm{K}$; K1, K2, K3, K4 and $\mathrm{K} 5$ of KS 100\%, $75 \% \mathrm{KS}+25 \% \mathrm{KF}, 50 \%$ $\mathrm{KS}+50 \% \mathrm{KF}, 25 \% \mathrm{KS}+75 \% \mathrm{KF}$ and $\mathrm{KF} 100 \%\left(100 \%\right.$ is $\left.95 \mathrm{~kg} \mathrm{~K} \mathrm{ha}^{-1}\right)$

Fig.1. Effect of potassium sulphate or potassium feldspar treated with silicate dissolving bacteria on available potassium during different periods after sowing.

\section{Economical choice}

Data presented in Table 5 show the most practical and economical treatment of potassium sulphate, K-feldspar and SDB applied on maize production $(\mathrm{Mg}$ $\mathrm{ha}^{-1}$ ), calculated in LE and the price of one $\mathrm{Mg}$ (grains) is $=1500 \mathrm{LE}$ and one $\mathrm{Mg}$ of stover dry weight is $=100 \mathrm{LE}$, on the other hand, the price cost of one $\mathrm{Mg}$ of potassium sulphate is $=7000 \mathrm{LE}$, one $\mathrm{Mg}$ of $\mathrm{K}$-feldspar is $=800 \mathrm{LE}$ and one liter of SDB is $=$ one LE according to 2014 prices.

The flowing equation was used in each treatment to calculate:

Production $\left(\mathrm{LE} \mathrm{ha}^{-1}\right)=\left\{\right.$ grains $\left(\mathrm{Mg} \mathrm{ha}^{-1}\right)^{*} 1500+$ Stover dry weight $\left(\mathrm{Mg} \mathrm{ha}^{-1}\right)$ * 100)

Production cost $\left(\mathrm{LE} \mathrm{ha}{ }^{-1}\right)$ for treatment $=\left\{\left(\right.\right.$ Potassium sulphate $\left.\mathrm{kg} \mathrm{ha}^{-1} * 7\right)+$ $\left(\mathrm{K}\right.$ - feldspar $\left.\mathrm{Kg} \mathrm{ha}^{-1} * 0.8\right)+\mathrm{SDB} \quad \mathrm{L} / \mathrm{Kg}$ feldspar $\left.* 1\right\}$

Revenue $\left(\mathrm{LE} \mathrm{ha}^{-1}\right)=\left\{\right.$ Production $\left(\mathrm{LE} \mathrm{ha}^{-1}\right)-$ Production cost $\left.\left(\mathrm{LE} \mathrm{ha}^{-1}\right)\right\}$

Data presented in Table 5 show the effect of different sources of potassium fertilizers (potassium sulphate and K-feldspar with SDB) on maize production $\left(\mathrm{Mg} \mathrm{ha}^{-1}\right)$. The application of $50 \%$ potassium sulphate plus $50 \% \mathrm{~K}$-feldspar + SDB exhibited the maximum revenue (11271 $\mathrm{LE} \mathrm{ha}^{-1}$ ) compared to $100 \%$ potassium sulphate (9379 $\left.\mathrm{LE} \mathrm{ha}^{-1}\right)$. 
TABLE 5. Effect of potassium sulphate and potassium feldspar treated with silicate dissolving bacteria on maize revenues

\begin{tabular}{|l|c|c|c|}
\hline \multicolumn{1}{|c|}{ Treatment } & $\begin{array}{c}\text { Production } \\
\text { (LE) }\end{array}$ & $\begin{array}{c}\text { Production Costs } \\
(\text { LE) }\end{array}$ & $\begin{array}{c}\text { Revenue } \\
\text { (LE) }\end{array}$ \\
\hline K0 & 6139 & 000 & 6139 \\
\hline K1 & 11045 & 1666 & 9379 \\
\hline K2 & 8683 & 1589 & 7094 \\
\hline K3 & 12783 & 1512 & 11271 \\
\hline K4 & 7568 & 1435 & 6133 \\
\hline K5 & 9192 & 1359 & 7833 \\
\hline Means & 9235 & 1260 & 7975 \\
\hline
\end{tabular}

Treatments are K0: no $-\mathrm{K} ; \mathrm{K} 1, \mathrm{~K} 2, \mathrm{~K} 3, \mathrm{~K} 4$ and $\mathrm{K} 5$ of $\mathrm{KS} 100 \%, 75 \% \mathrm{KS}+25 \% \mathrm{KF}, 50 \% \mathrm{KS}+50 \%$ $\mathrm{KF}, 25 \% \mathrm{KS}+75 \% \mathrm{KF}$ and $\mathrm{KF} 100 \%\left(100 \%\right.$ is $\left.95 \mathrm{~kg} \mathrm{~K} \mathrm{ha}^{-1}\right)$.

In general, addition of $50 \%$ potassium sulphate plus $50 \% \mathrm{~K}$ - feldspar + SDB showed favorable effects on maize production and maximum revenue as compared to $\mathrm{K} 1, \mathrm{~K} 2, \mathrm{~K} 4$ and $\mathrm{K} 5$ with an increase 20, 58, 83 and 44\%, respectively.

\section{Conclusion}

There were positive effects of application of $\mathrm{K}$ - feldspar in combination with SDB mixed with K-sulphate at a ratio of 1:1 (50\% potassium sulphate $+50 \% \mathrm{~K}$ feldspar) in production of maize yield and uptake of NPK. The treatment of (K3) gave the highest values of available potassium in soil compared to other treatments. Using the naturally deposited materials of K-feldspar combined with SDB would be beneficial for farmers and save high costs of chemical fertilizers.

\section{References}

Abd El-Baky, M.M.H., Ahmed, A.A., El-Nemr, M.A. and Zaki, A.F. (2010) Effect of potassium fertilizers and foliar zinc application on yield and quality of sweet potato. Res. J. Agric. Biological Sci., 6 (4), 386-394.

Abd El-Hakeem, S.S. and Fekry, W.A. (2014) Effect of K-feldspar, potassium sulphate and silicate dissolving bacteria on growth,yield and quality of sweet potato plants. Zagazig J. Agric. Res., 41 (3), 467-477.

Abdel-Salam, M.A. and Shams, A.S. (2012) Feldspar- K fertilization of potato (Solanum tuberosm L.) augmented by biofertilizer. Am-Euras. J. Agric. Environ. Sci., 12 (6), 694-699.

Abou-el-Seouda, B. and Abdel-Megeed, A. (2012) Impact of rock materials and biofertilizations on $\mathrm{P}$ and $\mathrm{K}$ availability for maize (Zea Maize) under calcareous soil conditions. Saudi J. Biol. Sci., 19 (1), 55-63.

Bader, M.A. (2006) Efficiency of K-feldspar combined with organic materials and silicate-dissolving bacteria on tomato yield. Journal of Applied Sciences Research, 2, 1191-1198.

Egypt. J. Soil Sci. 56, No. 2 (2016) 
Bader, M.A., Shafei, A.M. and Sharaf El-Deen, S.H. (2006) The dissolution of K and P-bearing minerals by silicate dissolving bacteria and their effect on sorghum growth. Res. J. Agric. Biol. Sci., 2 (1), 5-11.

Bakken, A.K., Cautneb, H. and Myher, K. (2005) The potential of crushed rocks and mine tailings as slow-releasing $\mathrm{K}$ fertilizers assessed by intensive cropping with Italian ryegrass in different soil types. Nutrient Cycling in Agric Systems, 47 (1).

Bennett, P.C., Choi, W.J. and Rogera, J.R. (1998) Microbial destruction of feldspars. Miner. Manage. 8 (6), 149-150.

Black, C.A. (1968) Soil Plant Relationships. $2^{\text {nd }}$ ed. John Wiley and Sons, NY,USA.

Blum, A.E. and Stillings, L.L. (1995) Feldspar dissolution kinetics. In Chemical Weathering Rates of Silicate Minerals (A.F. White and S.L. Brantley (Ed.) Mineralogical Society of America, Washington, DC, 31, 291-351.

Chapman, D.H. and Pratt, P.F. (1961) Methods of Analysis for Soils, Plants and Waters. California. Univ.; Division of Agric. Sci.,USA.

Dawwam, G.E., Elbetagy, A., Emara, H.M., Abbas, I.H. and Hassan, M.M. (2013) Beneficial effect of plant growth promoting bacteria isolated from the roots of potato plant. Ann. Agric. Sci., 58 (2), 195-201.

Ekin, Z. (2010) Performance of phosphate solubilizing bacteria for improving growth and yield of sunflower (Helianthus annuus L.) in the presence of phosphorus fertilizer. Afr. J. Biotech. 9 (25), 3794-3800.

Eweda, W.E., Selim, S.M., Mostafa, M.I. and Abd El-Fattah, D.A. (2007) Use of Bacillus circulans as bio-accelerator enriching composted agricultural wastes identification and utilization of the microorganism for compost production. In : Proceedings of the $12^{\text {th }}$ Conference of the Microbiology organized by The Egyptian Soc. of App. Micro. (ESAM), Giza, Egypt, 18-20, pp. 43-65.

Fancelli, A. and Dourado, D.N. (2003) Corn: Management strategies for high productivity. $1^{s t}$ ed. 208 p. Piracicaba: ESALQ-USP-LPV.

Foth, H.D. (1990) Fundamentals of Soil Science ( $8^{\text {th }}$ ed.) John Willy and Sons. New York, USA.

Girgis, M.G.Z., Heba, M.A. and Sharat, M.S. (2008) In vitro evaluation of rock phosphate and potassium solubilizing potential of some Bacillus strains. Aust. J. Basic Appl. Sci., 2 (1), 68-81.

Jackson, M.L. (1958) "Soil Chemical Analysis". Prentice Hall, Ine., Englewood Cliffs, New Jersy, USA.

Labib, B.F., Ghabour, K., Rahim, I.S. and Wahba, M.M. (2012) Effect of potassium bearing rock on the growth and quality of potato crop (Solanum tuberosum). J. Agric. Biotech. Sustainable Dev. 4 (1), 7 -15. 
Manning, D.A.C. (2010) Mineral sources of potassium for plant nutrition. A Review, Agron. Sustain, Dev., pp. 281-294.

Merwad, A.M.A., Awad, E.A.M., Mohamed, I.R. and Dahdouh, S.M.M. (2013) Effect of some phosphatic fertilizers and soil amendments on the availability of phosphorus in soil. Zagazig J. Agric. Res., 40 (3), 483-494.

Paes, M.C.D. (2008) Physical, chemical and technological aspects of maize grains. In Cruz JC, Karam D., Monteiro MAR, Magalhães PC (Ed.) The Culture of Maize. 1st ed. Sete Lagoas: Embrapa Maize and Sorghum. 517 p.

Piper, C.S. (1950) "Soil and Plant Anaylsis". Interscince Publishers Inc. New York, USA.

Priyanka, P. and Sindhu, S.S. (2013) Potassium Solubilization by Rhizosphere Bacteria: Influence of Nutritional and Environmental Conditions. J. Micro. Res., 3 (1), 25-31.

Priyono, J. and Gilkes, R.J. (2008) High-Energy milling improves the effectiveness of silicate rock fertilizers: A Glasshouse Assessment. Communicat. In Soil Sci. Plant Anal., 39 (34), 358-369.

Setiawati, A. and Handayanto, E. (2010) Role of phosphate solubilizing bacteria on availability phosphorus in Oxisols and tracing of phosphate in corn by using 32P. In: $19^{\text {th }}$ World Congress of Soil Science, Soil Solutions for a Changing World, Brisbane, Australia.

Sheng, X.F. (2005) Growth promotion and increased potassium uptake of cotton and rape by a potassium releasing strain of Bacillus edaphicus. Soil Biol. Biochem. 37, 19181922.

Sheng, X.F. and Huang, W.Y. (2002) Mechanism of potassium release from feldspar affected by the strain NBT of silicate bacterium. Acta Pedol. Sin. 39, 863-871.

Sheng, X.F., He, L.Y. and Huang, W.Y. (2002) The conditions of releasing potassium by a silicate-dissolving bacterial strain NBT. Agric. Sci. China., 1, 662-666.

Sugiyama, M. and Ae, N. (2006) Effect of potassium uptake by crop species on solubilization of silicate in a soil. Book Series: Developments in Plant and Soil Sci : plant nutrition, food securely and sustainability of agro-ecosystems through basic and applied research, Springer Netherlands.

Ullman, W.J., Kirchman, D.L. and Welch, S.A. (1996) Laboratory evidence for microbially mediated silicate mineral dissolution in nature. Chem. Geol., 132, 11-17.

Vessey, K.J. (2003) Plant growth promoting rhizobacteria as biofertilizers. Plant Soil, 255, 571-586.

Watanabe, F.S. and Olsen, S.R. (1965) Test of ascorbic acid method for determing phosphorus in water and $\mathrm{NaHCO}_{3}$ extracts from soil. Soil Sci. Soc. Am. Proc. 29, $677-$ 678.

Egypt. J. Soil Sci. 56, No. 2 (2016) 
Xiong, D., Li-feng, Z., Hui-bin, L., Fu-cun, Y. and Xiu-ju, B. (2007) Effects of potassium application on nutrient absorption dynamics, biomass and quality formation of forage maize. Acta Metallurgica Sinica, Journal of Plant Nutrition and Fertilizer 13 (3), 393.

Zakaria, A.A.B. (2009) Growth optimization of potassium solubilizing bacteria isolated from biofertilizer. Bachelor of Chem. Eng. (Biotech.), Fac. of Chem., Natural Resources Eng. Univ., Malaysia Pahang, p.40.

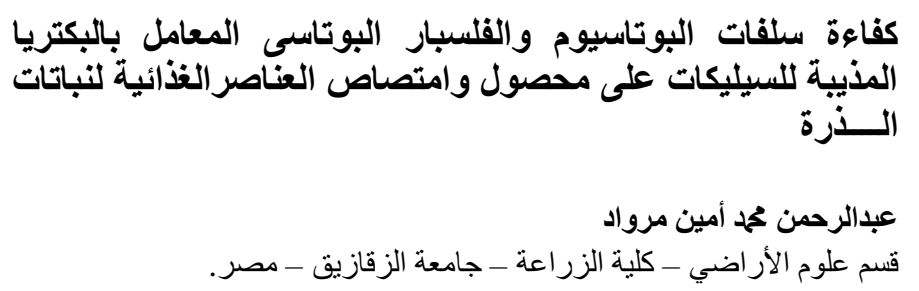

أجريت تجربة حقلية خلال موسم 2014 بهويا محافظة الثرقية - مصر لدراسة

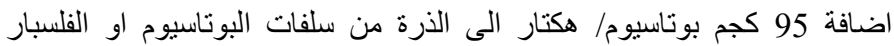

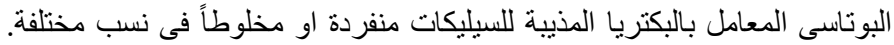

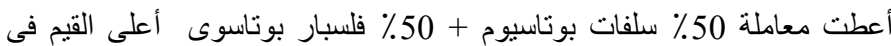

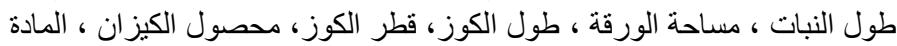

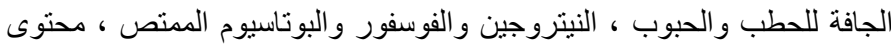

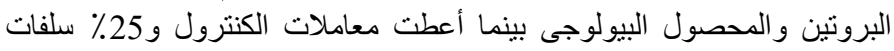

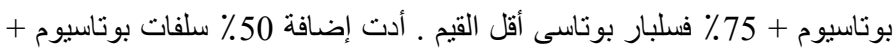

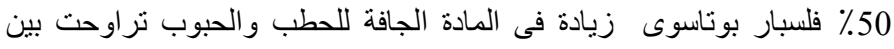

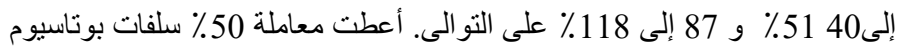

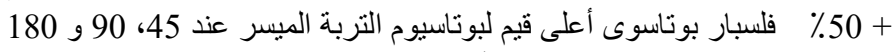

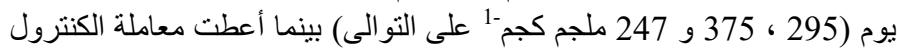

أقل القيم ( 63 ، 58 و 5151 و 247 ملجم كجم-1 على التو الىى). 